\title{
(ㄷ)
}

Research Paper

EPRA International Journal of Economic and Business Review-Peer Reviewed Journal

Volume - 9, Issue - 7, July 2021 | e-ISSN: 2347 - 9671| p- ISSN: 2349 - 0187

SJIF Impact Factor (2021): 8.302 || ISI Value: 1.433 || Journal DOI URL: https://doi.org/10.36713/epra2012

\section{ROLE OF PERFORMANCE PLANNING PRACTICES ON HUMAN RESOURCE TEAM BUILDING}

\author{
Dr. Srijib Shankar Jha \\ Associate Professor, Department of Travel \& Tourism Management, Siliguri Institute of Technology, \\ Sukna, District: Darjeeling (W.B), Pin code: 734009
}

\begin{abstract}
DOI No: 10.36713/epra7949

Article DOI URL: $\underline{\text { https://doi.org/10.36713/epra7949 }}$

Numerous organisations' efforts in recent years have been directed toward strategies that increase individual contributions to the organization's overall success. Numerous authors have investigated the connections between various facets of human resource management practises and their effect on employee effectiveness. Additionally, while it is widely accepted that human resource management is positively related to organisational and employee performance, considerable interest has grown in understanding the relationship between HRM and performance in the Indian context. The purpose of this paper is to determine the extent to which performance management system variables are associated with employee attitudes, particularly team building. The study employs both quantitative and qualitative methods; based on the information gleaned from the literature review, structured questionnaires were used to collect data from 200 employees in four organisations, which were then analysed statistically. The findings indicate that the majority of performance planning elements have a positive and significant correlation with team building.
\end{abstract}

KEYWORDS : performance planning, team building, employee attitude, human resource management.

\section{INTRODUCTION}

Numerous organisations' efforts in recent years have been directed toward strategies that maximise individual contributions to the organization's overall success. This nearly indispensible process is referred to as 'performance management.' Performance management (PM) evolved from a combination of performance appraisals and performance measurement systems to become a more holistic complex measurement and management system. Organizational performance management systems were becoming increasingly complex, taking into account factors other than financial indicators and focusing on the organization's long-term viability. Since the mid1990 's, there has been a significant increase in academic and applied research (Thorpe \& Beasley, 2004; Neely, 1999) into the areas of organisational performance measurement and performance management, both organisational and individual (Thorpe \& Beasley, 2004; Neely, 1999). Performance management is a much broader and more complicated human resource function, as it encompasses activities such as collaborative goal setting, continuous progress review and frequent communication, feedback and coaching for improved performance, implementation of employee development programmes, and rewarding 
accomplishments. The performance management process begins with the integration of a new incumbent into a system and concludes when an employee leaves the organisation. Performance management can be defined as a systematic process for enhancing an organization's overall performance through the enhancement of individual performance within a team framework. The performance management system's (PM system's) critical practises include the following: a precise job description; connecting employees to organisational goals through clear performance expectations that are observable and measurable; planning employee training and competency development; coaching practises; and regular performance evaluation and appraisal (Murphy and Cleveland, 1996; Arvey and Murphy, 1998; DeNisi, 2000; Graham, 2004; Armstrong and Baron, 2004). Employee performance is monitored and evaluated on a regular basis, and fits into a broader strategy of regular communication with employees.

\section{SECTOR OF TOURISM AND HOSPITALITY}

Tourism and hospitality are two of the world's largest service industries, and have been significant social activities for humans since time immemorial. The desire to discover new places, whether within one's own country or abroad, and to seek a change of environment and knowledge dates all the way back to ancient times. Tourism is the collection of all the phenomena and relationships that result from interactions between tourists, host governments and communities, businesses, and non-governmental organisations that are involved in the process of attracting, transporting, hosting, and managing these tourists and other visitors. Tourism has continued to grow and diversify over the last few decades, becoming one of the world's fastest growing economic sectors. Tourism now generates more revenue than oil exports, food products, or automobiles. Tourism has developed into a major player in international commerce, while also serving as a primary source of revenue and employment in a number of developing countries. Tourism's global expansion has benefited the economy and created jobs in a variety of related sectors, from construction to agriculture and telecommunications. Tourism is India's largest service industry, accounting for 6.23 percent of GDP and 8.78 percent of total employment. India receives over 5 million foreign tourists each year and 562 million domestic tourists. India's tourism industry generated approximately USD 28.50 billion in foreign exchange in 2018. (Source: Statistics from the Ministry of Tourism, Government of India, 2018).

While the future of tourism and hospitality in India is certainly exciting, the industry faces several human resource challenges, including a shortage of qualified staff at both operational and managerial levels and a significant gap between supply and demand side inputs. Additionally, most organisations in the industry still lack professionalism in terms of human resource management practises. For example, low salaries, long work hours, an insufficient career path, a lack of professional growth, a lack of training and development, and an insufficient work-life balance are all major issues encountered in the tourism industry. Managing employee performance is one of the most difficult challenges facing tourism and hospitality organisations today, as it is entirely dependent on an employee's commitment, competence, and clarity of performance. It is widely accepted that if employees are managed effectively through a well-designed reward system and feedback mechanism, this can serve as a critical tool for employee motivation and development.

\section{STATEMENT OF PROBLEM}

The need for answers regarding 'how to prioritise' and 'what is most important' in performance management interventions in the tourism industry appears to be a pertinent research challenge. Additionally, given the dearth of research demonstrating the extent to which multiple elements of performance management contribute to team building, the following two research questions appear to be pertinent:

1. Does effective performance management elicit the attitudes and responses necessary for employees to perform optimally?

2. What are the impediments to successful performance planning implementation?

The study is significant for tourism organisations because it demonstrates how performance management can improve business processes and contribute to the development of robust and reliable business systems in the Indian context. The study will aid in comprehending and identifying the factors that influence both individual and organisational performance. The research will make recommendations for effective measures that the tourism organisation can implement to reduce employee attrition and improve teamwork, leadership, motivation, employee commitment, and performance.

\section{LITERATURE REVIEW}

The findings of numerous international studies summarised in Boselie et al. (2005) and Katou, and Budhwar (2006) indicate that there are parallels and also contradictions in HRM and performance research. Huselid (1995) used factor analysis to develop and validate indexes of high-involvement human resource management practises. He discovered a strong and 
positive correlation between high-involvement human resource management practises and various measures of organisational performance, including work attachment, firm financial performance, and productivity. Delaney and Huselid (1996) discovered that practises consistent with a high-engagement human resource management strategy, such as highly selective staffing, incentive compensation, and training, were positively associated with organisational performance in another study. Subsequent empirical research has revealed reasonably strong, positive relationships between the extent to which a firm adopts highinvolvement human resource management strategies and organisational performance (MacDuffie 1995; Delery and Doty 1996; Youndt, Snell, Dean and Lepak 1996; Huselid, Jackson and Schuler 1997; Ichniowski et al. 1997; Chadwick and Cappelli 1998; Katou and Budhwar 2007).

Numerous authors have examined the relationship between individual human resource management practises and corporate financial performance. For example, Lam and White (1998) found that firms' human resource orientations (as measured by effective recruitment, above-average compensation, and extensive training and development) were associated with increased return on assets, sales growth, and stock value growth. Richard and Johnson (2001) examined the effect of strategic human resource management effectiveness (ratings of how effectively a variety of human resource practises were performed) on a number of performance variables using a sample of banks. They discovered that the effectiveness of strategic human resource management was directly related to employee turnover, and that the relationship between this metric and return on equity was stronger for banks with a higher capital intensity.

According to studies demonstrating a positive effect of training on firm performance, training is critical for increasing competitive advantage (FairfieldSonn, 1987), improving output quality (Holzer et al., 1993), facilitating organisational growth, and increasing profitability (Bartel, 1994). Kalleberg andMoody (1994) concluded that training appears to improve all aspects of firm performance, including product quality, product development, employee relations, sales growth, profitability, and market share. Additionally, training is viewed as a valuable tool for adapting to changes brought about by technological innovation, market competition, organisational structure, and demographic shifts (Knoke and Kalleberg, 1994). Russel, Terborg, and Powers (1985) established a correlation between employment training programme adoption and financial performance. Performance appraisal contributes to the improvement of business operations, efficiency (Alexander, 1989), defect elimination (Youndt et al., 1996), product reliability and productivity (Alexander, 1989), and overall organisation performance (Alexander, 1989). (Casio, 1989; Redman et al., 1993). Martell et al. (1996) discovered a positive correlation between four appraisal variables (frequency of informal appraisals, use of objective criteria, use of subjective criteria, and use of appraisal results) and firm performance. Roberts (1995) demonstrated in a study of 3000 businesses worldwide that a well-managed, professional appraisal system can significantly improve employee performance and firm profitability. Employing performance appraisals (Borman 1991) and associating them with compensation has also been consistently associated with increased firm profitability (Gerhart and Milkovich 1990). According to Koch and McGrath (1996), firms with more sophisticated staffing practises (planning, recruiting, and selection) had a higher labour productivity. The relationships between incentive compensation systems and firm performance imply that incentive compensation contributes to improved product quality, increased acceptance of change, and improved firm performance (Hiltrop, 1996; Luthans, 1998). Murphy (1985) examined the relationships between firm performance and incentive compensation for 461 executives in 72 firms over an 18-year period and discovered that executive compensation, which includes salary and bonus as well as stock options, stock holdings, and deferred compensation, was significantly and positively related to both shareholder returns and sales growth.

The majority of research on human resource management and performance has been conducted in the United States, and more recently in the United Kingdom over the last decade. The issue that arises is whether US and UK-centric models, however appropriate for the US, hold up in other contexts. Numerous researchers from outside the United States have built on this foundation in recent years to contribute to this literature. Harel and Tzafrir (1999) discovered that human resource practises were associated with perceived organisational and market performance in both public and private organisations in Israel. Lee and Miller (1999) discovered a correlation between human resource practises and performance in a sample of Korean firms. In their study of human resource strategy in Pacific Rim countries, Bae, Chen, Wan, Lawler, and Walumba (2003) discovered that, on average, high-performance work systems worked effectively, albeit under extremely variable conditions. Morishima (1998) discovered widespread acceptance of the contingency perspective in a sample of Japanese businesses. Ngo, Turban, Lau, and Lui (1998) discovered that certain work practises (training and compensation techniques) with a high degree of involvement tended to improve organisational performance in Hong Kong firms. Tsai (2006) found 
that effective employee empowerment practises have a positive correlation with organisational performance in Taiwan. Zheng, Morrison, and O'Neill (2006) investigated high-performance human resource management practises in 74 Chinese SMEs and discovered that despite performance-based pay, participatory decision making, free market selection, and performance evaluation, only high-level employee commitment was identified as the critical human resource management outcome for improving performance.

\section{METHODOLOGY OF RESEARCH}

Probability sampling is used in this research because it ensures that every item in the universe has an equal chance of being included in the sample. Due to the fact that the population from which the sample is drawn is not homogeneous, a stratified sampling technique is used to obtain a representative sample. Under stratified sampling, the population is subdivided into several strata that are more homogeneous individually than the total population. Each organisation receives a proportionate number of samples from each strata, ensuring that each organisation receives adequate representation regardless of its size. Thus, in probability sampling, a proportionate stratified random sampling method is used to interview 200 managers and executives from four travel companies in Kolkata, eastern India, namely Thomas Cook India Limited, Kuoni India Limited, Yatra.com, and Club 7 Holidays.

Employees in various positions at the aforementioned Indian travel companies were surveyed using a structured questionnaire to ascertain their perceptions and feedback regarding performance management in relation to their performance. To ensure proportionate representation from each of the four selected organisations, equal percentages of respondents were chosen from each organization's total managers and executives. Additionally, different strata or ranges of employees' years of experience in that particular organisation were classified, and a proportionate number of samples were randomly selected from within each strata. Given that the majority of the above-mentioned organisations employ between 50 and 150 people, a sufficient number of respondents was obtained to provide a representative sample of the total number of employees and a sufficient amount of data for analysis. Quantitative data were extracted from the questionnaire using a 5-point Likert scale response format. The verbal anchors ranged from "2 = strongly agree" to "-2 = strongly disagree".

\section{VARIABLES}

Dependent Variable

\begin{tabular}{|l|ll|}
\hline \multicolumn{1}{|c|}{ Variable } & \multicolumn{1}{c|}{ Description } \\
\hline Team building & $\begin{array}{l}\text { Loyalty: The extent to which employees are committed to work for the company. } \\
\text { - } \begin{array}{l}\text { Identification: The extent to which employees treat the company as if it were their own and } \\
\text { feel hopeful, motivated and enthusiastic about the company. }\end{array} \\
\text { - Involvement: The extent to which employees are willing to exert considerable effort and do } \\
\text { their best to take the company forward. }\end{array}$ \\
\hline
\end{tabular}

\section{Independent Variables}

\begin{tabular}{|l|l|}
\hline \multicolumn{1}{|c|}{ Variables } & \multicolumn{1}{c|}{ Description } \\
\hline $\begin{array}{l}\text { Context and } \\
\text { purpose }\end{array}$ & $\begin{array}{l}\text { Awareness - strategy: The extent to which the vision, strategy and the team's } \\
\text { purpose and contribution towards the strategy are communicated and understood. }\end{array}$ \\
\hline $\begin{array}{l}\text { Focus and } \\
\text { responsibility }\end{array}$ & $\begin{array}{l}\text { Specific responsibilities: The extent to which performance requirements are clarified and agreed on } \\
\text { in terms of objectives, goals and measures which are fair, realistic and achievable }\end{array}$ \\
\hline $\begin{array}{l}\text { Skills and } \\
\text { development }\end{array}$ & $\begin{array}{l}\text { Current: The extent to which skills requirements for current job effectiveness are specified, } \\
\text { development areas are agreed, and appropriate training / coaching are provided. } \\
\text { Future: The extent to which career plans exist and skills requirements for future job requirements } \\
\text { are developed. }\end{array}$ \\
\hline Resources & $\begin{array}{l}\text { Materials: The extent to which required resources are made available in terms of the physical } \\
\text { working environment and workspace. } \\
\text { Methods: The extent to which required resources are made available in terms of effective and user- } \\
\text { friendly operating systems, processes, job aids, procedure } \\
\text { manuals, policies and checklists. }\end{array}$ \\
\hline $\begin{array}{l}\text { Monitoring and } \\
\text { feedback }\end{array}$ & $\begin{array}{l}\text { Feedback frequency: The extent to which feedback is frequent and regular on top of bi-annual } \\
\text { performance discussions } \\
\text { Feedback quality: The extent to which feedback is adequate, gives employees a chance to explain }\end{array}$ \\
\hline
\end{tabular}




\begin{tabular}{|l|l|}
\hline & $\begin{array}{l}\text { difficulties, resolve problems and find ways to improve their performance. } \\
\text { Objectivity: The extent to which monitoring and evaluations of performance are fair and based on } \\
\text { facts. }\end{array}$ \\
\hline Consequences & $\begin{array}{l}\text { Perceived link 'performance-reward': The extent to which employees believe that there is a link } \\
\text { between their contribution, reward and remuneration. } \\
\text { Recognition: The extent to which employees feel their efforts are recognized and supported. } \\
\text { Disciplinary approach: The extent to which employees perceive that poor } \\
\text { performance is dealt with. }\end{array}$ \\
\hline
\end{tabular}

\section{HYPOTHESIS}

Positive linear relationships exist between the performance management practices (context, focus, resources, development, monitoring, and consequences) and Team building.

\section{DATA ANALYSIS}

Table 1

Correlations between variables

\begin{tabular}{|l|c|}
\hline $\begin{array}{l}\text { Correlations } \\
\text { Marked correlations are significant at } \mathrm{p}<0.001 \\
\mathrm{~N}=200\end{array}$ \\
\hline & Team building \\
\hline Context & 0.53 \\
\hline Focus & 0.63 \\
\hline Resources & 0.50 \\
\hline Development & 0.63 \\
\hline Monitoring \& Feedback & 0.56 \\
\hline Consequence & 0.62 \\
\hline
\end{tabular}

As seen in Table 1, the results indicate that a substantial (moderate correlation coefficient of between 0.40 and 0.69$)$ and significant $(p<0.05)$ relationship exists between all the performance management practices and team building. Substantial positive correlations were reported between context and Team building $(\mathrm{r}=0.50 ; \mathrm{p}<0.05)$; development and team building $(\mathrm{r}=0.63, \mathrm{p}<0.05)$; feedback and team building $(\mathrm{r}=0.56, \mathrm{p}<0.05)$; and consequences and team building $(\mathrm{r}=0.63, \mathrm{p}<0.05)$. Hypothesis, stating that performance management practices have a positive effect on team building has thus been corroborated.

\section{REGRESSION OF TEAM BUILDING ON PERFORMANCE MANAGEMENT PRACTICES}

As indicated in Table 3 team building was significantly predicted by all six performance management practices, namely consequences $(\mathrm{t}=8.63$, $\mathrm{p}<0.001)$, development $(\mathrm{t}=6.71, \mathrm{p}<0.001)$, focus $(\mathrm{t}=5.61, \mathrm{p}<0.001)$, resources $(\mathrm{t}=4.49, \mathrm{p}$ $<0.001)$, context $(\mathrm{t}=2.89, \mathrm{p}<0.01)$, and monitoring and feedback $(\mathrm{t}=-2.01 ; \mathrm{p}<0.05)$.

Table 2

Regression of Team Building on Performance Management Practices

Regression Summary for Dependent Variable: Commit

$\mathrm{R}=.72419757 \mathrm{R}^{2}=.52446212$ Adjusted $\mathrm{R}^{2}=.52163435$

$F(6,1009)=185.47 p<0.0000$ Std.Error of estimate: 3.5896

\begin{tabular}{|l|l|l|l|l|l|l|}
\hline & \multicolumn{1}{|c|}{ Beta } & $\begin{array}{c}\text { Std. Err. Of } \\
\text { Beta }\end{array}$ & \multicolumn{1}{|c|}{ B } & Std. Err. Of B & t & p-level \\
\hline Intercept & & & 0.462942 & 0.289684 & 1.598091 & 0.110336 \\
\hline Context & 0.090636 & 0.031324 & 0.108496 & 0.037496 & 2.893544 & 0.003891 \\
\hline Focus & 0.213850 & 0.038087 & 0.154770 & 0.027565 & 5.614759 & 0.000000 \\
\hline Resources & 0.122648 & 0.027297 & 0.120924 & 0.026914 & 4.493047 & 0.000008 \\
\hline Development & 0.237253 & 0.035377 & 0.164332 & 0.024504 & 6.706449 & 0.000000 \\
\hline Mnt Fdback & -0.076187 & 0.037843 & -0.054942 & 0.027291 & -2.013226 & 0.044356 \\
\hline Consequence & 0.280670 & 0.032531 & 0.295873 & 0.034293 & 8.627890 & 0.000000 \\
\hline
\end{tabular}


Together the six performance management practices could account for $52.44 \%$ of the variance in team building scores.

Based on the findings reflected in Table 2, Hypothesis, stating that performance management practices (context, focus, resources, development, monitoring and consequences) can be used to predict team building has been corroborated.

\section{CONCLUSIONS}

The primary objective of this research was to conduct an empirical examination of the relationship between performance management practises and team building in the Indian tourism sector, as well as to determine the relative importance of various practises in generating these outcomes. To accomplish this, the hypotheses proposed by a theoretical model were empirically tested. This finding implies that leaders / managers who effectively provide context and purpose, focus and responsibility, development opportunities, resources, performance monitoring and feedback, as well as consequences - as defined by Shirley's (2005) High Performance Practices model - are associated with employees experiencing high levels of job satisfaction.

This finding is consistent with the literature and empirical research indicating that employees are committed to their jobs when they can see the strategic relevance of their goals in relation to the organization's plans and objectives, participate actively in goal setting, perceive their goals to be clear, and receive frequent performance bonuses. Additionally, this finding is consistent with the literature, which indicates that employees are committed to a work environment in which leaders/managers articulate a vision, foster acceptance of group goals, establish high performance expectations, provide tailored support, and challenge employees to think differently about problems and work challenges, all of which are actions. The findings also support the notion that employees are committed in an environment where leaders / managers assign or secure agreements on what needs to be done, monitor deviations from standards and take corrective action, and promise or actually reward employees for satisfactorily completing the assignment, all of which are actions encomitant.

\section{REFERENCES}

1. Amba-Rao, S.C., Petrick, J.A., Gupta, J.N.D., and Von der Embse, T.J. (2000), 'Comparative Performance Appraisal Practices and Management Values among Foreign and Domestic Firms in India,' International Journal of Human Resource Management, 11, 1, 60-89.

2. Amaratunga, D., \& Baldry, D. (2002). Moving from performance measurement to performance management. Facilities, 20 (5/6), 217-223.

3. Alexander, $F$ (1989). Performance appraisals. SmallBusiness Reports, 14(3), 20-29.

4. Bae, J., Chen, S., Wan, T.W.D., Lawler, J.J., and Walumba, F.O. (2003), 'Human Resource Strategy and Firm Performance in Pacific Rim Countries,' International Journal of Human Resource Management, 14, 8, 1308-1332.

5. Bartel, AP (1994). Productivity record from the implementation of employee training programs.

6. Industrial Relations, 33(4), 411-425.

7. Becker, B.E. and Huselid, M.A. (1998), 'High performance work systems and firm performance: A synthesis of research and managerial implications.' In Personnel and Human Resource Management, v16, pp. 53-101.

8. Bhatnagar, J., and Sharma, A. (2005), 'The Indian Perspective of Strategic HR Roles and Organizational Learning Capability,' International Journal of Human Resource Management, 16, 9, 1711-1739.

9. Borman, WC (1991). Job behavior, performance, and effectiveness. In Handbook of Industrial and Organizational Psychology, 2nd edition, MD Dunnette and LM Hough (eds.). Palo Alto: CA Consulting Psychologists Press, 2271-1326.

10. BROWN, D. and ARMSTRONG, M. 1999. Paying for Contribution. Real Performance-related pay strategies. London: Kogan Page.

11. Budhwar, P., and Sparrow, P. (1998), 'National Factors Determining Indian and British HRM Practices: An Empirical Study,' Management International Review, 38, Special Issue 2, 105-121.

12. Casio, WF (1989). Managing Human Resources, 2nd ed. New York: McGraw-Hill.

13. Chadwick, G., and Cappelli, P. (1998), 'Investments or Contracts? The Performance Effects of Human Resource Systems under Contingencies,' working paper, Wharton School, University of Pennsylvania, Philadelphia.

14. Delaney, J.T., and Huselid, M.A. (1996), 'The Impact of Human Resource Management Practices on Perceptions of Organizational Performance,' Academy of Management Journal, 39, 4, 949-969.

15. Delery, J and D Doty (1996). Mode of theorizing in strategic human resources management: Tests of universalistic, contingency, and configurational performance predictions. Academy of Management Journal, 39(4), 802-35.

16. Dyer, L and T Reeves (1995). Human resource strategies and firm performance: What do we know and where do we need to go? International Journal of Human Resource Management, 6(3), 656-670.

17. Fletcher, C. (2001). Performance appraisal and management: The developing research agenda. Journal of Occupational and Organisational Psychology, 74 (4), 473-488.

18. Gerhart, B. (2005), 'Human Resources and Business Performance: Findings, Unanswered 
Questions and an Alternative Approach,' Management Revue, 16, 174-185.

19. Gerhart, B and GI Milkovich (1992). Employee compensation: Research and practice. In Handbook of Industrial and Organizational Psychology, MD Dunnette and LM Hough (eds.). Palo Alto: Consulting Psychologists Press.

20. GOLEMAN, D. 1996. Emotional Intelligence. Why it can matter more than IQ. London: Bloomsbury Publishing.

21. Management, 38, 3, 185-200.

22. Hiltrop, SM (1996). The impact of human resource management on organizational performance: Theory and research. European Management Journal, 14(6), 628-637.

23. Katou, A., and Budhwar, P. (2006), 'The Effect of Human Resource Management Systems on

24. Organizational Performance: Test of a Mediating Model,' International Journal of Human Resource Management, 17, 7, 1223-1253.

25. Kalleberg, AL and JM Moody (1994). Human resource management and organizational performance. The American Behavioral, 37(7), 948-962. Luthans, $K$ (1998). Using HRM to compete in the 2lst century. Management Quarterly, 38(4), 17-22.

26. KAPLAN, R.S. and NORTON, D.P. 1992. The Balanced Scorecard - measures that drive performance. Harvard Business Review. 70(1):7179.

27. KAPLAN, R.S. and NORTON, D.P. 1996. Linking the Balanced Scorecard to Strategy. Harvard: Harvard Business School Press.

28. Koch, M.J., and McGrath, R.G. (1996), 'Improving Labor Productivity: Human Resource Management Policies Do Matter,' Strategic Management Journal, 17, 5, 335-354.

29. Kock, R., Roodt, G., \& Veldsman, T.H. (2002). The alignment between effective people management, business strategy and organisational performance in the banking and insurance sector. South African Journal of Industrial Psychology, 28 (3), 83-91.

30. Kotter, J.P., \& Heskett, J.L. (1992). Corporate culture and performance. New York: The Free Press.

31. Martell, $K$ and SJ Carroll (1995). Which executive human resource management practices for the top management team are associated with higher firm performance? Human Resource Management, 34(4), 497-512.

32. Murphy, KJ (1985). Corporate performance and managerial remuneration: An empirical analysis. Journal of Accounting and Economics, 7(1-3), 1142.

33. Morishima, M. (1998), 'Changes in Japanese Human Resource Management: Implications for Firm Performance,' paper presented at Workplace Conflict and Cooperation: Prospects for Employee Representation, University of Urbana-Champaign, 1-2 May.
34. NEELY, A., GREGORY, M. and PLATTS, K. 1995. Performance measurement system design. A literature review and research agenda. International Journal of Operations and Production Management. 15(4):80-116.

35. Ngo, H.-Y., Turban, D., Lau, C.-M., and Lui, S.-Y. (1998), 'Human Practices and Firm Performance of Multinational Corporations: Influences of Country of Origin,' International Journal of Human

36. Resource Management, 9, 4, 632-652.

37. Paul, A.K., and Anantharaman, R.N. (2003), 'Impact of People Management Practices on Organizational Performance: Analysis of a Causal Model,' International Journal of Human Resource Management, 14, 7, 1246-1266.

38. Pratt, H.J. (1991). Principles of Effective Performance Management. Records Management

39. Quarterly. Vol. 23 No.1. 28. - 33.

40. Russel, J.S., Terborg, J.R., and Powers, M.L. (1985), 'Organizational Performances and Organizational Level Training and Support,' Personnel Psychology, 38, 849-863.

41. Sangweni, S.S. (2003). Performance Management as a Leadership and Management Tool. Senior Management Services Conference.15 -17 June.

42. Schuler, R.S., and Jackson, S.E. (2005), 'A Quarter-century Review of Human Resource Management in the US: The Growth in Importance on the International Perspective,' Management Revue, 16, 11-35.

43. Spangenberg, H.H., \& Theron, C.C. (2001). Adapting the Systems Model of Performance Management to major changes in the external and internal organisational environments. South African Journal of Business Management, 32 (1), 35-47.

44. Stashevsky, S., \& Koslowsky, M. (2006). Leadership team cohesiveness and team performance. International Journal of Manpower, 27 (1), 63-74.

45. Steyn, A.G.W., Smit, C.F., Du Toit, S.H.C., \& Strasheim, C. (1995). Moderne Statistiek vir die Praktyk. Pretoria: Van Schaik Publishers.

46. Theron, C.C., \& Spangenberg, H.H. (2000). Confirmatory factor analysis of the performance management audit questionnaire. South African Journal of Psychology, 30 (4), 32-39.

47. TOBIN, D.R. 1998. The knowledge-enabled organization. Moving from 'Training' to 'Learning' to Meet Business Goals. New York: Amacom.

48. Tsai, C.-J. (2006), 'High Performance Work Systems and Organizational Performance: An Empirical Study of Taiwan's Semiconductor Design Firms,' International Journal of Human Resource Management, 17, 9, 1512-1530.

49. Tsui, A.S., Pearce, J.L., Porter, L.W. and Tripoli, A.M. (1997). 'Alternative approaches to the employee-organisation relationship: does investment in employees pay off?' In Academy of Management Journal, v40, pp. 1089-21. 
50. Venkatraman, N., and Ramanujam, V. (1986), 'Measurement of Business Performance in Strategy Research: A Comparison of Approaches,' Academy of Management Review, 11, 801-814.

51. Van Dijk, \& H.C. Thornhill, C. (2003). Implementing Performance $M$ anagement to enhance

52. Development. South Africa Journal of Public Administration. Vol.38. 464-467.

53. Williams, R.S. (2002). Managing Employee Performance. Design and Implementation in

54. Organisation.2nd ed. Singapore: Senge Lee Press.

55. Youndt, MA, SA Snell, JW Dean and DP Lepak (1996). Human resource management, manufacturing strategy, and firm performance. Academy of Management Journal, 39(4), 836-866.

56. Zheng, C., Morrison, M., and O'Neill, G. (2006), 'An Empirical Study of High Performance HRM

57. Practices in Chinese SMEs,' International Journal of Human Resource Management, 17, 10,17721803. 